[26] International Guiding Principles for Biomedical Research Involving Animals (1985). Genebra: CIOMS, 28. Available at: https:/cioms.ch/publications/product/international-guiding-principles-for-biomedical-research-involving-animals-2/

[27] Soroka, N. M., Dashchenko, S. O. (2017). Clinical cases of strongyloidosis of dogs in Kiev. Actual problems of veterinary parasitology at the present stage. Vitebsk, 116-120. Available at: http://repo.vsavm.by/handle/123456789/3866

[28] Paradies, P., Iarussi, F., Sasanelli, M., Capogna, A., Lia, R. P., Zucca, D. et. al. (2017). Occurrence of strongyloidiasis in privately owned and sheltered dogs: clinical presentation and treatment outcome. Parasites \& Vectors, 10 (1). doi: http:// doi.org/10.1186/s13071-017-2275-5

[29] Pires, M. L., Dreyer, G. (1993). Revendo a importância do Strongyloides stercoralis. Revista do Hospital das Clinicas, 48, 175-182.

\title{
INTENSITY OF INVASION IN EMERIOSIS OF RABBITS IN DIFFERENT METHODS OF KEEPING
}

\author{
Oksana Shkromada \\ Department of therapy, pharmacology, clinical diagnostics and chemistry ${ }^{1}$ \\ oshkromada@gmail.com \\ Tetiana Nedzheria \\ Department of therapy, pharmacology, clinical diagnostics and chemistry ${ }^{1}$ \\ tatyananedzheria@ukr.net \\ ${ }^{1}$ Sumy National Agrarian University \\ 160 Herasyma Kondratieva str., Sumy, Ukraine, 40021
}

\footnotetext{
Abstract

One of the important problems in raising rabbits is eimeriosis, regardless of the method of maintenance. The disease affects animals of all ages, causing weight loss, feed conversion, morbidity and death.

The aim. Study of the prevalence and diagnosis of rabbit eimeriosis by different housing technology to improve methods of disease control.

Methods. The experiment was conducted during 2017-2019 in farms with different capacities in four regions of Dnipro, Zaporizhia, Kharkiv and Sumy. A total of 20 farms for keeping rabbits of different breeds were surveyed.

Results. Studies of rabbit farms on business and private ones found that the most common infestation was with the following species of eimeria: Eimeria perforans, E magna, E. media, E. irresidua, E. piriforms and E. intestinalis. It is proved that the extensiveness of rabbit infestation when kept in farms in metal cages, under the conditions of sanitary and hygienic regime and timely disinvasion of premises, was in the range of $42-15 \%$ in autumn-winter period, and $19-6 \%$ in spring-summer. According to the survey of homestead farms, rabbits kept in wooden cages on deep litter, the level of invasion in the autumn-winter period was $100-56 \%$ and in the spring-summer $-70-29 \%$.

Conclusions. Keeping rabbits in metal cages in compliance with sanitary and hygienic standards and timely disinvasion reduces the level of extensiveness of the invasion.

Keywords: eimeriosis of rabbits, biological cycle of eimerias, intensity of invasion, methods of keeping rabbits.
}

DOI: $10.21303 / 2504-5679.2020 .001419$

\section{Introduction}

The rabbit industry in Ukraine is just beginning to gain momentum due to the rapid growth and dietary properties of meat. Rabbits are an alternative commodity to fill meat stocks, as well 
as kept them as pets and laboratory animals. Rabbit meat has a high content of protein, linolenic acid, calcium and phosphorus, low fat and cholesterol, also due to the physiological characteristics of rabbits in the process of their cultivation uses a minimum amount of chemotherapeutic agents. Therefore, such products can be considered organic. What is currently relevant for the food industry and maintaining the ecological balance in general $[1,2]$.

Increasing the intensity of rabbit breeding and the concentration of livestock in a limited area increases the risk of disease transmission. Since Eimerias are permanent residents of gastrointestinal rabbits, the transmission of the pathogen from mother to children in the first days of life is inevitable. Coccidia oocysts are excreted along with rabbit feces. Oocysts can exist for a long time in the environment and one is enough to invade the next host. Rabbits together with hay, water and eating the feces of the mother and each other can be infected with this parasite [3].

Coccidiosis (eimeriosis) of rabbits (Oryctolagus cuniculus) refers to a parasitic disease caused by different species of the family Eimeria class Coccidia. There are eleven species of eimeria that live in the gastrointestinal tract and one that may exist in the bile ducts - Eimeria stiedae. [4].

Rabbits can be infected with coccidia from the environment. Very often this happens in breeding centers and other breeding enterprises where there is a large concentration of animals. Oocysts (eggs) need two or more days in humid conditions to become invasive. Rabbits can also become infected by eating oecyst-infected Eimeria grass and feed. In such conditions, it is important to disinfect the premises for animals $[5,6]$.

Hepatic coccidiosis is caused by Eimeria stiedai. Young rabbits can be very susceptible, especially if exposed to an environment with a high level of invasion. Infection of animals with Eimeria stiedai can lead to obstruction of the bile ducts and fibrous formations in the liver. Clinically, it looks like weight loss, diarrhea, ascites, and jaundice, depending on the severity of the infection. Eimeria perforans, E. magna, E. media and E. irresidua are the four main species that cause intestinal coccidiosis in rabbits. Coccidia are located in the ileum and colon. Often coccidiosis can be diagnosed after the death of the animal. Typical symptoms are flatulence, loss of appetite, rapid weight loss, and sometimes diarrhea. The cause of death of animals is intoxication and asphyxia [7, 8].

Prevention of coccidiosis depends on proper sanitation and keeping the litter dry. First of all, prevent contamination with fecal masses of water and food. It is also necessary to avoid feeding rabbits from the floor $[9,10]$. One way to reduce the number of oocysts is to have walking areas for rabbits. Sunlight ultraviolet light destroys coccidia eggs.

The aim of the research was to determine the geographical features of the prevalence of species of rabbit coccidia and the dependence of cases on the method of keeping animals and the sanitary condition of cages.

\section{Materials and methods}

The research was conducted from 2017 to 2020 in four regions - Dnipro, Zaporizhia, Kharkiv and Sumy. During the research the following were taken into account: the system of keeping rabbits, the type of premises, sanitary and hygienic indicators of the premises.

A total of 20 farms for keeping rabbits of different breeds were surveyed. The diagnosis of eimeriosis was made by laboratory tests of rabbit feces by the method of Fulleborn. The number of oocysts per gram of feces was determined according to the method of McMaster [11], and Eimeria species were identified using morphological criteria. Prophylactic and forced cell disinfection was performed with the help of Contavir (manufactured by "Kronos Agro", Ukraine) at a dose of $100 \mathrm{ml}$ per $1 \mathrm{~m}^{2}$, which also has disinvasive properties against oocysts.

\section{Results}

The life cycle of coccidia is directly dependent on the method of keeping, the age of the animals, the season of the year and other factors. In view of this, to study coccidiosis (eimeriosis) as a disease caused by coccidia, to predict an increase in invasion, to plan preventive and curative measures, taking into account seasonality. Researches on detection of infestation by coccidiosis of rabbit farms of a farming and private direction were carried out (Table 1). 
Table 1

Species composition of coccidia, which are found in farms and private enterprises for keeping rabbits

\begin{tabular}{|c|c|c|}
\hline \multirow{2}{*}{ Types of Eimeria } & \multicolumn{2}{|c|}{ Rabbit farms } \\
\hline & Business & Private \\
\hline \multicolumn{3}{|c|}{ Dnipro region } \\
\hline E. perforans & - & + \\
\hline E. magna & + & ++ \\
\hline E. media & + & ++ \\
\hline E. irresidua & ++ & +++ \\
\hline E. stiedae & - & + \\
\hline E. intestinalis & - & + \\
\hline \multicolumn{3}{|c|}{ Zaporizhia region } \\
\hline E. magna & + & ++ \\
\hline E. media & ++ & +++ \\
\hline E. irresidua & ++ & +++ \\
\hline E. stiedae & - & + \\
\hline E. intestinalis & + & + \\
\hline \multicolumn{3}{|c|}{ Sumy region } \\
\hline E. exigua & + & +++ \\
\hline E. perforans & - & + \\
\hline E. piriforms & + & +++ \\
\hline E. flavescens & - & + \\
\hline E. magna & + & + \\
\hline E. media & + & +++ \\
\hline \multicolumn{3}{|c|}{ Kharkiv region } \\
\hline E.perforans & - & + \\
\hline E. magna & - & ++ \\
\hline E. media & + & +++ \\
\hline E. irresidua & + & ++ \\
\hline E. piriforms & - & + \\
\hline E. intestinalis & + & ++ \\
\hline
\end{tabular}

Note: «++++»-75-100\% distribution of Eimeria species; “+++”- 50-75\%; “++”-25-50\%; “+”- Up to $25 \%$; “-”-Eimeria are absent

Experimentally obtained data from table 1 indicate that the most common types of Eimeria: Eimeria perforans up to $25 \%$, E. magna $25-50 \%$, E. media $50-75 \%$, E. irresidua 50-75\%, E. piriforms $25-50 \%$ and $E$. Intestinalis $25-50 \%$ (Fig. 1-6).

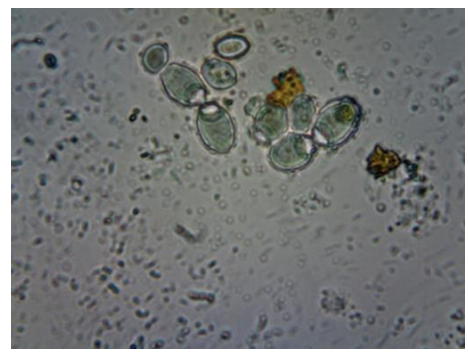

Fig. 1. Eimeria perforans 


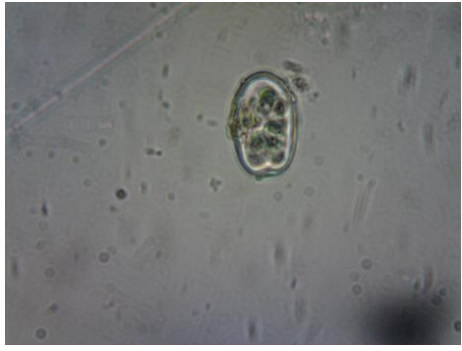

Fig. 2. Eimeria magna

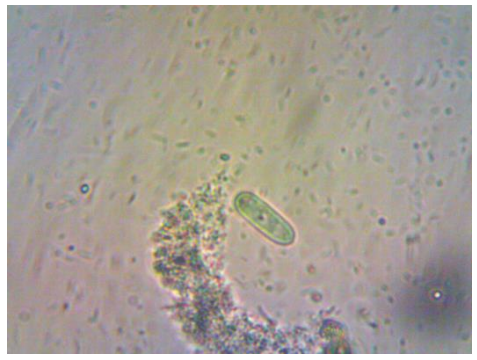

Fig. 3. Eimeria media

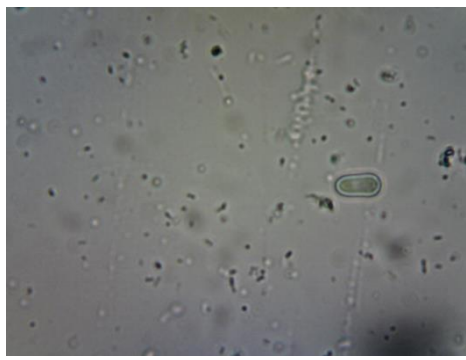

Fig. 4. Eimeria irresidua

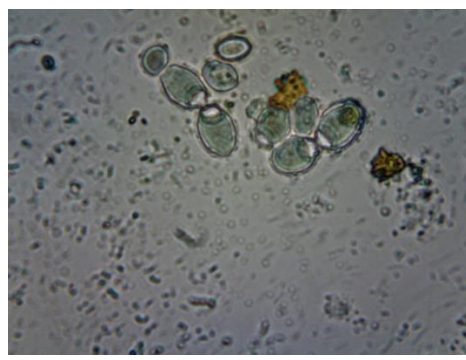

Fig. 5. Eimeria piriforms

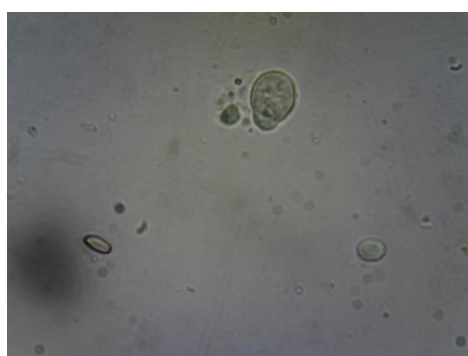

Fig. 6. Eimeria Intestinalis

Mixed invasion has always been detected in business and private (homestead) farms. But the percentage of cases of coccidiosis is higher in private households, in which there are, depending 
on the season, up to 100-200 heads. In our opinion, this is due to the way rabbits are kept and the sanitary and hygienic condition of the premises [12, 13].

Cage keeping of rabbits on farms. Premises in which rabbits kept divided into two types summer open and enclosure cells with brick heating. Open cages in three tiers for keeping in the warm period of the year (autumn, summer and spring) are made of metal mesh. Ventilation in such cells occurs naturally, the temperature varies depending on the environment $15-22{ }^{\circ} \mathrm{C}$. The main problem of this method of maintenance is to maintain the sanitary condition of the cells. Although the floor is made of mesh and rabbits cannot eat from the floor, infection can occur through food and water. Coccidia oocysts can also be trapped even on metal cages and other equipment. Rabbits have the ability to periodically lick the surrounding objects and each other, thus re-infecting animals in the group. Up to eight animals are kept in each cage. As a rule, all animals are the same age. But before landing in one group they are taken from different cages from the mother and divided into males and females. Thus groups are formed. Therefore, groups are mixed with varying degrees of invasion. In enclosure cells, rabbits are kept in metal cages in one tier. Nipple drinkers, bunker-type feeders, to which access is free. In cages one uterus with rabbits. The lighting in the room is artificial. Forced mechanical ventilation of supply and exhaust type. The room temperature is $17-19^{\circ} \mathrm{C}$ in winter and $23-25^{\circ} \mathrm{C}$ in summer.

On farms, regular mechanical cleaning of cages from rabbit manure is carried out. Disinfection takes place with the Kercher washing machine only when rabbits are transferred from one age group to another. Faecal samples for the study were taken from rabbits of different age groups (Table 2).

Table 2

The level of infestation of rabbits with eimeria in farms of Ukraine when kept in metal cages, $n=15$

\begin{tabular}{|c|c|c|c|}
\hline Farm & Season & The number of eymeric oocysts in the field of view of the microscope & EI, \% eimeriosis \\
\hline \multirow{2}{*}{1} & Autumn-winter & $23 \pm 1.5$ & 29 \\
\hline & Spring-summer & $15 \pm 1.2$ & 19 \\
\hline \multirow{2}{*}{2} & Autumn-winter & $30 \pm 3.15$ & 38 \\
\hline & Spring-summer & $14 \pm 0.8$ & 17 \\
\hline \multirow{2}{*}{3} & Autumn-winter & $12 \pm 5.5$ & 15 \\
\hline & Spring-summer & $9 \pm 0.5$ & 11 \\
\hline \multirow{2}{*}{4} & Autumn-winter & $12 \pm 1.2$ & 15 \\
\hline & Spring-summer & $7 \pm 2.5$ & 9 \\
\hline \multirow{2}{*}{5} & Autumn-winter & $30 \pm 0.4$ & 37 \\
\hline & Spring-summer & $6 \pm 3.4$ & 7 \\
\hline \multirow{2}{*}{6} & Autumn-winter & $25 \pm 0.5$ & 31 \\
\hline & Spring-summer & $8 \pm 3.5$ & 10 \\
\hline \multirow{2}{*}{7} & Autumn-winter & $13 \pm 3.0$ & 16 \\
\hline & Spring-summer & $5 \pm 2.0$ & 6 \\
\hline \multirow{2}{*}{8} & Autumn-winter & $34 \pm 2.4$ & 42 \\
\hline & Spring-summer & $14 \pm 1.5$ & 17 \\
\hline \multirow{2}{*}{9} & Autumn-winter & $25 \pm 3.2$ & 31 \\
\hline & Spring-summer & $10 \pm 2.0$ & 12 \\
\hline \multirow{2}{*}{10} & Autumn-winter & $20 \pm 1.8$ & 25 \\
\hline & Spring-summer & $7 \pm 0.5$ & 9 \\
\hline
\end{tabular}

Note: EI-Extensiveness of invasion 
As a result of an experiment carried out on caged farms, it was found that the extent of invasion of rabbits by Eimeria was in the range of 6-42\% and varied depending on the season. The main peak incidence of rabbit eimeriosis was observed in the autumn-winter period. It was proved that the maximum number of coccidia oocysts in the fecal masses of rabbits in the cold season was $34 \pm 2.4(\mathrm{EI}=42 \%)$, and the minimum $-12 \pm 1.2$ in the field of view of the microscope at $\mathrm{EI}=15 \%$. The results are related to the deterioration of the indoor microclimate, namely, increased humidity, poor ventilation and insolation. In the spring-summer period of the year, the level of invasion for eimeriosis decreased, and ranged from the maximum $-15 \pm 1.2$ ( $\mathrm{EI}=19 \%)$, to the minimum $-5 \pm 2.0(\mathrm{EI}=6 \%)$ [14]. According to the results of surveys of farms with a cage method of keeping rabbits, it can be stated that the incidence of rabbits for eimeriosis was within acceptable limits and did not exceed $42 \%$.

Keeping rabbits in wooden cages on private farms. In private homesteads, rabbits are kept in wooden cages with deep bedding. The temperature in the cages is not regulated and depends on the season, ventilation is natural. The walls and floor of the cages are solid wood, some elements of the cages can be made of metal mesh. The problem with keeping rabbits on a wooden floor with deep bedding is the accumulation of large amounts of fecal mass that rabbits can eat. Thus there is an invasion of all group of rabbits in a cage. Also a significant disadvantage is the material from which the cells are made - wood. Wood is a very porous material that can accumulate moisture, helminth eggs, eymeric oocysts and microorganisms. It is difficult to carry out disinfection and disinvasion in such cages as disinfection of a wood occurs only on its surface, without getting deep into material. This allows the reproduction of microorganisms in the pores of wood and sporulation of oocysts of Eimeria. Each cage can have a different number of rabbits from eight to ten. Faecal samples for the study were taken from rabbits of different ages (Table 3).

Table 3

Level of Eimeria infestation of rabbits in private farms of Ukraine when kept in wooden cages and on the floor, $\mathrm{n}=15$

\begin{tabular}{|c|c|c|c|}
\hline Farm & Season & The number of eymeric oocysts in the field of view of the microscope & EI, \% eimeriosis \\
\hline \multirow{2}{*}{11} & Autumn-winter & $50 \pm 4.3$ & 63 \\
\hline & Spring-summer & $46 \pm 2.5$ & 58 \\
\hline \multirow{2}{*}{12} & Autumn-winter & $65 \pm 2.83$ & 81 \\
\hline & Spring-summer & $34 \pm 1.5$ & 43 \\
\hline \multirow{2}{*}{13} & Autumn-winter & $72 \pm 4.5$ & 90 \\
\hline & Spring-summer & $56 \pm 2.4$ & 70 \\
\hline \multirow{2}{*}{14} & Autumn-winter & $62 \pm 3.2$ & 78 \\
\hline & Spring-summer & $28 \pm 3.3$ & 35 \\
\hline \multirow{2}{*}{15} & Autumn-winter & $80 \pm 5.4$ & 100 \\
\hline & Spring-summer & $42 \pm 2.8$ & 53 \\
\hline \multirow{2}{*}{16} & Autumn-winter & $76 \pm 4.5$ & 95 \\
\hline & Spring-summer & $48 \pm 3.5$ & 60 \\
\hline \multirow{2}{*}{17} & Autumn-winter & $56 \pm 4.7$ & 70 \\
\hline & Spring-summer & $23 \pm 2.6$ & 29 \\
\hline \multirow{2}{*}{18} & Autumn-winter & $45 \pm 3.8$ & 56 \\
\hline & Spring-summer & $24 \pm 4.4$ & 30 \\
\hline \multirow{2}{*}{19} & Autumn-winter & $67 \pm 5.2$ & 84 \\
\hline & Spring-summer & $43 \pm 3.0$ & 54 \\
\hline \multirow{2}{*}{20} & Autumn-winter & $63 \pm 1.25$ & 80 \\
\hline & Spring-summer & $32 \pm 1.9$ & 40 \\
\hline
\end{tabular}

Note: EI-Extensiveness of invasion 
Studies have shown that the highest peak of rabbit infestation with eimeriosis was in the autumn-winter period. This is due to a decrease in solar activity and the accumulation of fecal masses in the cells [15]. At low temperatures, the manure freezes to the cells, which complicates the process of mechanical cleaning and disinvasion of cells. The maximum number of coccidia in the fecal masses of rabbits in the cold season was $80 \pm 5.4(\mathrm{EI}=100 \%)$, and the minimum $45 \pm 3.8$ in the field of view of the microscope at $E I=56 \%$. In the spring and summer, the level of invasion decreased significantly, and ranged from the maximum $-56 \pm 2.4$ (EI=70\%), to the minimum $-23 \pm 2.6$ (EI=29\%). As a result of surveys conducted on private farms in Ukraine when keeping rabbits in wooden cages and on a solid floor, the incidence of eimeriosis was $100 \%$ in the autumn-winter period.

\section{Discussion}

Eimeriosis was monitored in twenty rabbit farms in four regions of Ukraine. Faecal samples collected from rabbits were examined for the number of Eimeria oocysts. Microscopic studies have shown that animals are most often infected with Eimeria perforans up to $25 \%$, E. magna $25-50 \%$, E. media 50-75\%, E. irresidua 50-75\%, E. piriforms $25-50 \%$ and E. Intestinal $25-50 \%[16,17]$. Depending on the intensity of the invasion and climatic conditions, the incidence rate can vary [18].

The study gives an idea of the infection rate of large farms was $25-50 \%$ and private $75-$ $100 \%$ [19]. Also important is the concentration of livestock, the system of keeping rabbits on metal mesh floors and on solid wood [20, 21]

Study limitations. The limitation of research is the insufficient number of covered farms, but gives a plausible idea of the level of invasion and species composition of coccidia in rabbit farms in Ukraine [22].

Prospects for further researches. Study of the intensity of rabbit infestation for eimeriosis depending on the methods of treatment and prevention scheme.

\section{Conclusions}

The obtained results show that in rabbit farms of farming business and private direction the most common infestation of the following species of Eimeria were: Eimeria perforans, E magna, E. media, E. irresidua, E. piriforms and E. intestinalis. Practical researches have proved that keeping rabbits in metal cages with observance of sanitary and hygienic norms and carrying out timely disinvasion reduces the level of rabbit diseases with eimeriosis.

The practical value of the experiments is to determine the species composition of coccidia and the level of infestation with eimeriosis in rabbit farms of Ukraine by different methods of maintenance.

\section{References}

[1] Nistor, E., Bampidis V. A., Pacala, N., Pentea, M., Tozer, J., Prundeanu, H. (2013). Nutrient Content of Rabbit Meat as Compared to Chicken, Beef and Pork Meat. Journal of Animal Production Advances, 3 (4), 172-176. doi: http://doi.org/10.5455/ japa.20130411110313

[2] Saidj, D., Aliout, S., Arabi, F., Kirouani, S., Merzem, K., Merzoud, S., Ainbaziz, H. (2013). La cuniculture fermiere en Algerie: Une source de viande non negligeable pour les familles rurales. Livestock Research for Rural Development, 25 (8). Available at: http://www.lrrd.org/lrrd25/8/said25138.htm Last accessed: 07.02.2018

[3] Laha, R., Das, M., Goswami, A. (2015). Coccidiosis in rabbits in a subtropical hilly region. Indian Journal of Animal Research, 49 (2), 231-233. doi:10.5958/0976-0555.2015.00064.3

[4] Maziz-Bettahar, S., Aissi, M., Ainbaziz, H., Bachene, M. S., Zenia, S., Ghisani, F. (2018). Prevalence of coccidian infection in rabbit farms in North Algeria. Veterinary World, 11 (11), 1569-1573. doi: http://doi.org/10.14202/vetworld.2018.1569-1573

[5] Oliveira, U. C., Fraga, J. S., Licois, D., Pakandl, M., Gruber, A. (2011). Development of molecular assays for the identification of the 11 Eimeria species of the domestic rabbit (Oryctolagus cuniculus). Veterinary Parasitology, 176 (2-3), $275-280$. doi: http://doi.org/10.1016/j.vetpar.2010.10.054

[6] Yin, G., Goraya, M. U., Huang, J., Suo, X., Huang, Z., Liu, X. (2016). Survey of coccidial infection of rabbits in Sichuan Province, Southwest China. SpringerPlus, 5 (1). doi: http://doi.org/10.1186/s40064-016-2586-6 
[7] Akpo, Y., Kpodékon, M. T., Djago, Y., Licois, D., Youssao, I. A. K. (2012). Vaccination of rabbits against coccidiosis using precocious lines of Eimeria magna and Eimeria media in Benin. Veterinary Parasitology, 184 (1), 73-76. doi: http://doi.org/ 10.1016/j.vetpar.2011.08.012

[8] Okumu, P. O., Gathumbi, P. K., Karanja, D. N., Mande, J. D., Wanyoike, M. M., Gachuiri, C. K. et. al. (2014). Prevalence, pathology and risk factors for coccidiosis in domestic rabbits (Oryctolagus cuniculus) in selected regions in Kenya. Veterinary Quarterly, 34 (4), 205-210. doi: http://doi.org/10.1080/01652176.2014.978044

[9] Sivajothi, S., Reddy, B. S., Rayulu, V. C. (2014). Study on impression smears of hepatic coccidiosis in rabbits. Journal of Parasitic Diseases, 40 (3), 906-909. doi: http://doi.org/10.1007/s12639-014-0602-8

[10] Silva, S. M., Ferreira, C., Paupério, J., Silva, R. M., Alves, P. C., Lemos, A. (2015). Coccidiosis in European rabbit (Oryctolagus cuniculus algirus) populations in the Iberian Peninsula. Acta Parasitologica, 60 (2). doi: http://doi.org/10.1515/ap-2015-0049

[11] McMaster egg counting technique: Principle. Available at: https://www.rvc.ac.uk/review/parasitology/EggCount/Principle.htm

[12] Henneb, M., Aissi, M. (2013) Etude Cinetique de L'excretion Oocystale Chez la Lapine et sa Descendance et Identification des Differentes Especes de Coccidies. Proc. 15emesJournees de la Recherche Cunicole. Le Mans, 221-224.

[13] Szkucik, K., Pyz-Łukasik, R., Szczepaniak, K. O., Paszkiewicz, W. (2013). Occurrence of gastrointestinal parasites in slaughter rabbits. Parasitology Research, 113 (1), 59-64. doi: http://doi.org/10.1007/s00436-013-3625-7

[14] Ilic, T., Stepanovic, P., Nenadovic, K., Dimitrijevic, S. (2018). Improving agricultural production of domestic rabbits in Serbia by follow-up study of their parasitic infections. Iranian Journal of Veterinary Research, 19 (4), $290-297$.

[15] Shkromada, O., Skliar, O., Paliy, A., Ulko, L., Suprun, Y., Naumenko, O. et. al. (2019). Development of preventing means for rabbits' coccidiosis. Eureka: Health Sciences, 3, 58-68. doi: http://doi.org/10.21303/2504-5679.2019.00914

[16] Tao, G., Wang, Y., Li, C., Gu, X., Cui, P., Fang, S. et. al. (2017). High pathogenicity and strong immunogenicity of a Chinese isolate of Eimeria magna Pérard, 1925. Parasitology International, 66 (3), 207-209. doi: http://doi.org/10.1016/j.parint.2017.01.014

[17] Li, C., Tao, G., Gu, X., Cui, Y., Wang, Y., Suo, J. et. al. (2019). Selection and identification of a precocious line of Eimeria intestinalis with enlarged oocysts and deletion of one generation of schizogony. Parasitology Research, 118 (3), $969-976$. doi: http://doi.org/10.1007/s00436-018-06199-1

[18] Yan, W., Wang, W., Wang, T., Suo, X., Qian, W., Wang, S., Fan, D. (2013). Simultaneous identification of three highly pathogenic Eimeria species in rabbits using a multiplex PCR diagnostic assay based on ITS1-5.8S rRNA-ITS2 fragments. Veterinary Parasitology, 193 (1-3), 284-288. doi: http://doi.org/10.1016/j.vetpar.2012.11.013

[19] Jing, F., Yin, G., Liu, X., Suo, X., Qin, Y. (2011). Large-scale survey of the prevalence of Eimeria infections in domestic rabbits in China. Parasitology Research, 110 (4), 1495-1500. doi: http://doi.org/10.1007/s00436-011-2653-4

[20] Papeschi, C., Fichi, G., Perrucci, S. (2013). Oocyst excretion pattern of three intestinal Eimeria species in female rabbits. World Rabbit Science, 21 (2), 77-83. doi: http://doi.org/10.4995/wrs.2013.1235

[21] Schlolaut, W., Hudson, R., Rödel, H. (2013). Impact of rearing mangement on health in domestic rabbits: a review. World Rabbit Science, 21 (3), 145-159. doi: http://doi.org/10.4995/wrs.2013.1029

[22] Abdel-Baki, A. A. S., Al-Quraishy, S. (2013). Prevalence of coccidia (Eimeria spp.) infection in domestic rabbits Oryctolagus cuniculus in Riyadh, Saudi Arabia. Pakistan Journal of Zoology, 45 (5), 1329-1333. 